\title{
Staying the Return of Aliens from Europe through Interim Measures: The Case-law of the European Commission and the European Court of Human Rights
}

\author{
Clara Burbano Herrera and Yves Haeck \\ Netherlands Institute of Human Rights, Utrecht University, Utrecht, The Netherlands \\ Human Rights Centre, Ghent University, Ghent, Belgium
}

\begin{abstract}
The Strasbourg case-law demonstrates a clear tendency to protect aliens through interim measures in case of imminent deportation. Usually but not uniquely those persons claim(ed) before the supervisory organs to be in a situation of extreme gravity in case of forcible return to their country of origin because they can be subject to the death penalty, life imprisonment, persecution for their political activities, deprived of medicine/adequate medical treatment. This contribution explores which typologies of cases have led the European Commission and Court to apply interim measures in those situations, as well as which rights and freedoms have been protected thereby.
\end{abstract}

\section{Keywords}

interim measures, aliens, expulsions, extraditions, European Court of Human Rights (ECHR)

\section{Introduction}

Presumably one of the most effective daily instruments at the disposal of persons who run an imminent risk of being expelled or extradited from an ECHR Member State is, in view of the non-suspensive effect of an application lodged with the European Court, to request the Court to issue an interim measure to stay their removal. It is a mechanism whose purpose is to prevent irreparable harm to persons in an extremely grave and urgent situation, and who are potential victims of a violation of an ECHR right, which a favourable final judgment would therefore not be able to undo. ${ }^{1}$ They result in immediate protection offered by the State in compliance with the order issued by the Court. Between 1974 and 2009, 2.207 measures have been issued. The number of requests is, however, much higher and is currently growing exponentially; from 444 in 2006 and 1.132 in 2007, to 3.178 requests in 2008 and 2.399 in $2009 .^{2}$ The success rate was $23,5 \%$ in 2008

1) ECtHR 10 March 2009, Paladi v Moldova, Appl. No. 39806/05, \$89; ECtHR 7 July 2009, Grori v Albania, Appl. No. 25336/04, \$184.

2) Statistical information provided by the Registry of the Court [on file with authors]; ECtHR, Annual Reports 2007, 2008, 2009, Strasbourg, pp. 137, 134, 146 respectively. 
and even $27,3 \%$ in 2009 , while previously it only amounted to $17 \%$ (20002007) and 15,2\% (1988-1998). ${ }^{3}$ Most are expulsion or extradition cases ${ }^{4}$ and in $75 \%$ have protected non-Europeans, ${ }^{5}$ so that it can be argued that a study of the case-law on interim measures is relevant, not only because it shows in which cases it has been applied, but also permits the illustration of the problems related to immigration/expulsion affecting contemporary society.

Following some introductory remarks (Section 2), this article explores which typologies of factual situations have led the supervisory organs to apply interim measures in expulsion/extradition cases and which rights have been protected (Section 3) and Dublin transfers and interim measures (Section 4). ${ }^{6}$ Some conclusions will be drawn from these cases (Section 5).

\section{Procedural Basis and Level of Proof}

Rule 39(1) of the Rules of Court holds that:

[t]he Chamber or, where appropriate, its President may, at the request of a party or of any other person concerned, or of its own motion, indicate to the parties any interim measure which it considers should be adopted in the interests of the parties or of the proper conduct of the proceedings before it.

Measures have been indicated "in limited spheres", namely in case of an imminent risk of irreparable damage, ${ }^{7}$ where no longer any suspensive domestic remedy is available against the disputed act, ${ }^{8}$ and if it is highly probable that the act will contravene the ECHR. ${ }^{9}$

\footnotetext{
3) Yves Haeck and Clara Burbano Herrera, 'Interim Measures in the Case-Law of the European Court for the Protection of Human Rights', Netherlands Quarterly of Human Rights, Vol. 3 (2003), p. 663.

4) Jean-Paul Costa, 'Séminaire sur le role des agents des gouvernements dans la protection effective des droits de l'homme' - Bratislava, 3 April 2008.

5) Clara Burbano Herrera, Provisional Measures as a Mechanism of Prevention of Violations of Human Rights in the Inter-American and European Human Rights System. Ph.D. Thesis, Ghent: Ghent University 2008, Vol. 2.

6) See also e.g. Eva Rieter, Preventing Irreparable Harm, Provisional Measures in International Human Rights Adjudication, Antwerp/Oxford: Intersentia 2010, pp. 265-306 and 817-842 and Clara Burbano Herrera and Yves Haeck, 'Letting States off the Hook. The Paradox of the Legal Consequences following State Non-compliance with Provisional Measures in the Inter-American and European Human Rights Systems', Netherlands Quarterly of Human Rights, Vol. 28 (2010), pp. 332-360.

7) ECtHR 4 February 2005, Mamatkulov and Askarov v Turkey, Appl. No. 46827/99, 46951/99, \$104.

8) ECommHR 18 October 1993, Barirv France, Appl. No. 19776/92. The rejection of an asylum request, not followed by an order to leave the country, is insufficient to justify an interim measure, given that the applicant cannot demonstrate that he is likely to become the victim of a violation of a Convention right (ECommHR 7 July 1992, D. v France, Appl. No. 19794/92). Also, no measure will be indicated if a new asylum request/request for a residence permit on humanitarian grounds can apparently be submitted in the light of new circumstances, and when rejected asylum seekers of a specific origin are no longer forcibly returned to a certain country. ECommHR, Balac v Netherlands, Appl. No. 47813/99.

9) Maud Buquicchio-de Boer, 'Interim Measures by the European Commission of Human Rights', in M. de Salvia a.o. (eds), The Birth of European Human Rights Law, Baden-Baden: Nomos 1998,
} 
A request for an interim measure has to be submitted in a credible form, supported by evidence demonstrating very prima facie the danger to which the applicant is/would be exposed if the measure were not adopted. ${ }^{10}$ This is a lower threshold than the level of proof required at the admissibility stage. It is insufficient to prove a general situation of danger in the receiving State, but he has to prove that he/she is personally, within that scenario, in a special situation that differentiates him/her from the rest of the population. ${ }^{11}$ However, being part of an ethnic minority under systematic physical threat, has, apart from further individual characteristics, induced the Court to suspend deportations until it was satisfied that, in the light of the specific personal circumstances of the person concerned, expulsion could be considered reconcilable with Article 3. ${ }^{12}$ It is therefore unnecessary for an individual to prove that he is more at risk than the other members of the group, as long as it is established, where necessary based on recent $\mathrm{NGO}$ or governmental reports, that there are reasons to believe in the existence of the practice concerned and his/her membership of the group. Indeed, insisting that an applicant show the existence of further special distinguishing features would render illusory the protection under Article $3 .{ }^{13}$

\section{Factual Situations}

The Strasbourg case-law shows a clear tendency to protect aliens through interim measures in case of imminent deportation/extradition because the person concerned risks: losing his life upon return (Article 2 ECHR), being ill-treated (Article 3 ECHR) or, exceptionally, being separated from his family (Article 8 ECHR). The Court has also left itself leeway to extend its application of interim measures to other rights, such as the prohibition of slavery (Article $4 \mathrm{ECHR}$ ), or the right to a fair trial (Article $6 \mathrm{ECHR}$ ), in case of 'flagrant denial' of the latter.

\subsection{Cases in which Life and Physical Integrity Have Been Protected}

\subsubsection{Beneficiaries Risking the Application of the Death Penalty (Articles 2 and 3 ECHR, Articles 1 Protocol 6 or 13, Article 6 ECHR)}

Persons fearing execution if forcibly returned to their country of origin/another country because they risk to be tried for the commission of a crime normally

pp. 230-233; Carl Aage Nörgaard and Hans Christian Krüger, 'Interim and Conservatory Measures under the European System of Protection of Human Rights', in Manfred Nowak a.o. (eds), Progress in the spirit of Human Rights, Kehl: Engel 1988, pp. 112-113.

10) Rieter speaks of 'prima prima facie' evidence. Rieter, supra note 6.

11) ECtHR 17 February 2004, Venkadajalasarma v Netherlands, Appl. No. 58510/00, \$68. ECtHR 4 July 2006, Karim v Sweden, Appl. No. 24171/05.

12) See President Court, 'Note Verbale' with interim measure, 3 May 2004, Appl. No. 15243/04.

13) ECtHR 17 July 2008, NA. v UK, Appl. No. 25904/0, \$116; ECtHR 11 December 2008, Muminov $v$ Russia, Appl. No. 42502/06, \$95. 
punished with the death penalty or because they have already been sentenced to death may lead to the adoption of an interim measure halting the expulsion/ extradition, in order to protect the right to life (Article 2, Article 1 Protocols 6/13), the prohibition of torture (Article 3 ECHR) or the right to a fair trial (Article 6 ECHR).

During the period in which capital punishment was permitted under Article 2, interim measures in death penalty cases were adopted to stay extradition/expulsion, by connecting the case with the prohibition of torture, where substantial grounds have been shown for believing that the person concerned faces a real risk of being ill-treated in the receiving country or a flagrant denial of due process. ${ }^{14}$ Thus, where a murderer alleged that an extradition to the US where he risked the death penalty, would expose him to the death row phenomenon - a long-term stay in a death cell - which in his opinion contravened Article 3, led to a request from the European Commission - later extended by the Court - to the UK to suspend the extradition of the German until the Strasbourg proceedings had ended. ${ }^{15} \mathrm{~A}$ measure was also issued to stay the expulsion of a US-Israeli citizen to US, following allegations that his extradition would violate Article 3 due to final irreducible life sentence of 845 years, with no possibility of parole and only a theoretical possibility of remission. ${ }^{16}$ In many cases where interim measures have been adopted, Article 3 has been invoked together with Article 2 and Protocol 6. ${ }^{17}$ It is interesting to observe that following the older case-law of the Court (before the Article 2 reversal), the petitioners sometimes only refer to Article 3 when requesting an interim measure, notwithstanding the possibility to invoke Protocol 6. So, in a Turkish case the applicant asked for the staying of an extradition order to the US because he ran the risk of being sentenced to death. In this case, no mention is made of Protocol 6 (or Article 2 ECHR), even though the interim measure was adopted in 2006, after Turkey had ratified that Protocol. ${ }^{18}$ The same can be seen in a Spanish case, where an extradition order of someone accused of being the spokesperson in Europe of a Peruvian terrorist organisation was stayed in order to protect the rights under Article 3. In this case it was, inter alia, alleged that there was a high risk that the applicant would be sentenced to death if

\footnotetext{
14) ECHR 7 July 1989, Soering v UK, Appl. No. 14038/88, \$88; ECtHR 20 March 1991, Cruz Varas a.o. $v$ Sweden, Appl. No. 15576/89, \$69-70.

15) Soering, supra note $14, \$ 4,77,88-92$ (detention period on death row - on average 6-8 years - would provoke, given youth and mental state, strong tensions and suffering that would violate Article 3).

16) ECtHR 13 June 2002, Weiss v Austria, Appl. No. 74511/01; ECtHR 16 October 2001, Einhorn v France, Appl. No. 71555/01 (claim violation Article 3 due to likelihood of serving irreducible life sentence and -as victim was found after restoration of death penalty - imposition of death penalty and thus exposition to death-row phenomenon; lifted after assurances by prosecutor).

17) ECtHR 15 March 2001, Ismaili v Germany, Appl. No. 58128/00 (interim measure staying extradition of Moroccan, who risked death penalty).

18) ECtHR 4 July 2006, Kordian v Turkey, Appl. No. 6575/06 (lifted after US guarantees not to impose death penalty).
} 
returned. ${ }^{19}$ As in the previous case, Spain had already ratified Protocol 6 when the measure was adopted. In other cases, even though the petitioners only mention Article 3, the Court has expanded its analysis by also referring to Article 2 and to Protocols 6 or 13. In one case the plaintiff claimed that if deported to Nigeria her life would be at risk, since it would expose her to capital punishment, and requested the adoption of interim measures to protect Article 3. The Court held that the considerations made regarding a deportation order that could endanger a person's life or physical integrity could be made on the basis of Article 3, as well as Article 2 and Protocol 13. The analysis of one of those articles, therefore, necessarily implied the study of the others. ${ }^{20}$ In this case, as in some aforementioned cases, the State had already ratified Protocols 6 and 13.

The latest Article 2 case-law has removed the exception permitting the death penalty and currently prohibits this punishment in all circumstances. Nowadays, if there are substantial grounds to believe that someone, if extradited/expelled would face a real risk that he will receive the death penalty in the receiving country, then Article 2 implies a prohibition to extradite/expel. Moreover, if the extradition/expulsion will almost certainly lead to the implementation of the death penalty, such extradition/expulsion may be regarded as an intentional deprivation of life, which is also prohibited. ${ }^{21}$ This view is illustrated in a British case concerning events in Iraq. On 30 December 2008, an interim measure was issued to halt the transfer by the British army of two Iraqi's accused of murdering British soldiers, to the Iraqi authorities (whose UN Mandate was to expire on 31 December 2008) following allegations that the beneficiaries would, inter alia, run a real risk of being killed in violation of their right to life (Article 2) or the abolition of the death penalty (Article 1 Protocol 13), being ill-treated (Article 3), or receiving an unfair trial (Article 6) upon rendition. ${ }^{22}$ In contrast, some years earlier, an interim measure requested by Saddam Hussein's lawyers - relying on Articles 2/3, Articles 1 Protocol 6 and 13 prohibiting the UK and the other ECHR Member States (of the US-led coalition in Iraq) from facilitating/allowing for/acquiescing in/participating in Saddam's transfer without Iraqi diplomatic assurances as to the nonapplication of the death penalty, was denied. ${ }^{23}$ While the UK was already bound by Protocols 6/13, the measure was rejected, (most seemingly) because Saddam was not under the jurisdiction of British or other European forces just because

\footnotetext{
19) ECtHR 10 August 2006, Olaechea Cahuas v Spain, Appl. No. 24668/03, \$63-72 (Spain incomplied, sent petitioner to Peru; violation Article 34).

20) ECtHR 21 September 2004/17 January 2006, Bello v Sweden, Appl. No. 32213/04.

21) ECtHR 19 November 2009, Kaboulov v Russia, Appl. No. 41015/04; ECtHR 2 March 2010, Al-Saadoon and Mufdhi v UK, Appl. No. 61498/08, $\$ 123$.

22) Al-Saadoon and Mufdhi, supra note 21, $44,78-81,162-165$ (failure to comply with measure and transfer out of UK jurisdiction exposed applicants to serious risk of grave and irreparable harm; violation Article 34).

23) Press release 337, "European Court of Human Rights rejects request for interim measures by Saddam Hussein”, 30 June 2004.
} 
they formed part of a coalition, as the transfer was carried out by the US in its own zone and it had the coalition command. ${ }^{24}$

\subsubsection{Beneficiaries who Are Seriously ill (Articles 2 and 3 ECHR)}

The health of foreigners has led to the adoption of interim measures, when it is alleged that implementing an deportation/extradition order could imply the violation of the prohibition of torture (Article 3) or the loss of life (Article 2), because, due to the very serious state of the applicants health, it would either be hazardous to undertake a voyage to the country of origin or, even if the trip were not dangerous, the receiving country could not offer adequate medical treatment.

\subsubsection{Temporary Ill and in Urgent Need of an Operation or Special Care} Interim measures have been adopted to stay the removal of a person who is temporarily ill and urgently requires an operation or special care, which consequently means that he/she cannot be forced to leave the Member State immediately since his/her return to his/her country of origin could place him/her in danger.

This subgroup contains types of situations such as: that of a heavily pregnant woman whose order of deportation is stayed because according to medical certificates, the birth could result in complications (Article 2) and, therefore, it was highly recommended that the deportation be stayed, ${ }^{25}$ that of a man scheduled to have an operation the day prior to the implementation of the deportation order (Articles 2 and 3) ${ }^{26}$ or a Ghanese man who had, according to medical examinations, to have an eye operation for glaucoma (at very short notice) (Article 3). ${ }^{27} \mathrm{In}$ each case, measures were adopted but the application was ultimately declared inadmissible because the risk of irreparable damage had disappeared. An interim measure has also been issued to stay the removal of persons whose psychiatric condition was such that it could lead to a suicide attempt, as substantiated in a medical report ${ }^{28}$ or to those who suffer post-traumatic stress disorder due to their experiences in their countries of origin, which are usually facing an internal armed conflict or in which there are reported acts of discrimination toward a certain

\footnotetext{
24) The case was therefore declared inadmissible. ECtHR 14 March 2006, Hussein v Albania, Appl. No. 23276/04.

25) ECommHR 15 May 1996, Poku v UK, Appl. No. 26985/95.

26) ECtHR 15 November 2001, Karagoz v France, Appl. No. 47531/99 (Turk sentenced and to leave country, but prison doctor certified that he needed an operation - scheduled before day of deportation - and then had to follow a simple, but uninterrupted treatment).

27) ECtHR 19 May 1994, Tanko v Finland, Appl. No. 23634/94 (claim of inadequate facilities for treatment/operation in Ghana).

28) ECommHR 14 September 1995, Bhuyian v Sweden, Appl. No. 26516/95; ECtHR 22 May 2001, Taskin v Germany (Appl. No. 56132/00) (staying expulsion of Turkish immigrant, who had received medical treatment in hospital on one occasion, whose medical file mentioned depression and motor problems).
} 
social group. ${ }^{29}$ In some instances, the combination of mental problems and a physical illness have also lead to an interim measure staying a deportation, such as in the case of a mother and daughter in Germany - of which the mother suffered from depression and hepatitis $\mathrm{C}$ and claimed that the receptor State, Romania, could not offer the necessary medical treatment for her illness. ${ }^{30}$ On the other hand, an interim measure was not issued with regard to an imminent expulsion to Pakistan for a physically disabled person. ${ }^{31}$

\subsubsection{Irreversibly and Fatally Ill}

Persons suffering from more serious diseases, given their irreversible and fatal nature, have benefited from interim measures. In these cases, the treatment needed is much longer and expensive (than that of the first subgroup), meaning that it is necessary to determine whether the petitioner should remain in the Member State for an extended period. This subgroup in general comprises HIV-infected persons and/or having developed AIDS ${ }^{32}$ or who suffer from other, serious and complicated disorders/diseases, such as schizophrenics, where treatment/medicines were allegedly not available in their country of origin (Article 3), ${ }^{33}$ a young Azerbaijani anorexic female who received specialised medical treatment and who had been admitted to a children's hospital for short time-spans (Article 3). ${ }^{34}$ A special case concerns persons who were not sick themselves, but whose deportation was stayed because of an emotional and family bond with a terminally-ill person, who had been granted the facility to stay for humanitarian reasons. ${ }^{35}$

In HIV-AIDS cases it is interesting to note that, while this does not play a role at the moment interim measures have to be adopted, distinctions are made in each of the cases by the Court as to the true health of the petitioner, the extent to which the disease has developed, the possibilities that the beneficiary can

\footnotetext{
29) ECtHR 19 September 2006, Svarca v Sweden, Appl. No. 547/05 (Serbian family with health problems because of Kosovo war); ECtHR 5 September 2006, Haziri v Sweden, Appl. No. 37468/04; ECtHR 31 January 2006, Rubina v Sweden, Appl. No. 35733/04 and ECtHR 17 January 2006, Elezi v Sweden, Appl. No. 4244/05.

30) ECtHR 7 October 2004, Dragan v Germany, Appl. No. 33743/03.

31) ECommHR 13 May 1996, Choudry v UK, Appl. No. 27949/95.

32) ECtHR 2 May 1997, D. $v$ UK, Appl. No. 30240/96, $\$ 3$ (expulsion of terminally-ill aids-patient to St. Kitts; violation of Article 3 in the very exceptional circumstances of the case); ECommHR 25 October 1996, Lenga v France, Appl. No. 30011/96; ECtHR 27 May 2008, N. v UK, Appl. No. 26565/05.

33) ECtHR 6 February 2001, Bensaid v UK, Appl. No. 44599/98, $\$ 1$, 4, 34-40 (medical treatment, although under less favorable conditions, available in Algeria, so deportation would not violate Article 3; possible deterioration health was speculation; medicine needed not free but obtainable if admitted to hospital; alternative medicine could be found).

34) ECtHR 31 January 2006, Zade v Sweden, Appl. No. 41983/04 (Azerbaijan family whose asylum request had been denied because there was no information that the Azerbaijani authorities tolerated or supported acts of agression by Turkish population in Azerbaijan).

35) ECtHR 23 May 2006, Ragimova v Sweden, Appl. No. 5607/05.
} 
continue the treatment in the receptor State and the reasons why the State has decided to expel the plaintiff, differences that determine the outcome of the admissibility and/or merits of the application. These distinctions may, moreover, also play a role when the renewal of the interim measure is due.

\subsubsection{Beneficiaries who Fear Being Deported or Extradited to their Country of} Origin because of their Political Activities (Articles 2 and 3 ECHR)

Cases in which it is alleged that persons under deportation/extradition orders may be deprived of their life (Article 2) or subjected to acts incompatible with the prohibition of torture (Article 3 ) if they return to their countries of origin, as a consequence of their political ties, have also been protected by interim measures.

In a minority of cases, interim measures have been issued to protect the right to life. Whether a measure is issued to protect the right to life will depend on the specific situation and the type of risk that the beneficiaries are supposed to face upon arriving at their country of origin. ${ }^{36}$ Consequently, in the majority of cases, interim measures are aimed at protecting the prohibition of torture. ${ }^{37}$ Some of the beneficiaries of interim measures staying their expulsion or extradition admit to being members of a political opposition party, others are linked to alleged terrorist or illegal organisations and still others have some tie with a previous government.

Interim measures have been adopted to stay the deportation of a person belonging to a political party in opposition to the Bangladeshi government, ${ }^{38}$ a Belarusian national to Belarus, where he allegedly risked being ill-treated by law-enforcement authorities aiming at extracting from him a confession for fraud, but also in the ambit of an alleged political conspiracy and assistance to the opposition. ${ }^{39}$

A member of the Islamic Liberation Front which was outlawed in Algeria after having won the elections benefited from an interim measure staying his expulsion from Belgium in view of the fact that the person concerned risked losing his life if sent back, ${ }^{40}$ as was the case for a petitioner claiming that if returned to Cameroon he would be in danger, because he was a family member of the leader of a

\footnotetext{
36) ECommHR, 19 February 1998, Bahaddar v Netherlands, Appl. No. 25894, \$75-79; ECommHR 29 October 1998, Dehwari v Netherlands, Appl. No. 37014/97, \$7, 59-62 and ECtHR 27 April 2000, Dehwari v Netherlands, Appl. No. 37014/97, \$5, 17.

37) Some cases in which interim measures were adopted to protect Article 3: Karim, supra note 11 (expulsion to Bangladesh); ECtHR 27 June 2006, Osmanov and Osmanova v Sweden, Appl. No. 30977/05 (expulsion to Azerbeidjan); ECommHR 7 December 1989, Cruz Varas v Sweden, Appl. No. 15576/89; ECtHR 26 November 2002 Bilasi-Ashri v Austria, Appl. No. 3314/02.

38) ECtHR 12 October 2004 Liton v Sweden, Appl. No. 28320/03.

39) ECtHR 13 March 2007, Novik v Ukraine, Appl. No. 48068/06.

40) ECommHR 6 July 1995, Azzouza v Belgium, Appl. No. 27276/95; ECtHR 22 October 2002, Ammari $v$ Sweden, Appl. No. 60959/00 (Algerian claiming to be a member of the Armed Islamic Group, against his will); Press release 131, 19 February 2009 (staying of deportation of Jordanian extremist imam to Jordania).
} 
failed coup and had become a member of an armed faction following an attack on his village during which his mother and sisters were killed. ${ }^{41}$ The expulsion of a couple with two children, which claimed, inter alia, that, given the conflict in the former Yugoslavia, their lives would be in danger if they returned to their country because they had supported one of the parties, i.e. the Kosovo Liberation Army, was also stayed through an interim measure. ${ }^{42}$ Interim measures have also been adopted to stay the deportation of a stateless person to Israel or the Palestinian territories due to his activities for the Palestinian security services, who considered him a security risk vis-à-vis Israeli interests, ${ }^{43}$ or to halt the deportation of Tamils claiming a risk due to the collaboration they had provided to the outlawed Tamil Tigers, that sought to create an independent state within Sri Lanka through using violence. ${ }^{44}$ In the ambit of the third category, interim measures were adopted to stay the extradition of the applicant to Belarus who claimed that the authorities of his country had pressurised him to testify against a former official and he had been accused of abandoning his official duties. ${ }^{45}$ Interim measures have been issued staying the deportation of a Cameroonian who was in fear if he was returned because he was a witness in a trial involving the President of his country, ${ }^{46}$ or halting the deportation of a Congolese citizen, claiming to have been a member of the special military presidential division and as such had been responsible to protect the President and his entourage, and that, for this reason, he could not return to his country because the new administration had killed every old collaborator. ${ }^{47}$ Finally, an interim measure from the Court led to the suspension of the extradition of a Georgian national by Croatia to his home country, as it was alleged by the applicant that his extradition would result in his ill-treatment by the Georgian authorities, due to his affiliation with the ex-President of that country and with the former regime. ${ }^{48}$

In some cases not only the persons directly linked to political activities may be at risk, but also their relatives and therefore, interim measures have also been adopted to protect the latter. ${ }^{49}$

41) ECtHR 12 October 1999, Bodika v France, Appl. No. 48135/99 (also claims that family members were very ill, some had post-traumatic stress-disorder and the mother had attempted suicide three times).

42) Elezi, supra note 29.

43) ECtHR 4 April 2006, Shloun v Sweden, Appl. No. 17185/04.

44) Venkadajalazarma, supra note 11.

45) ECtHR, Kamyshev v Ukraine, Appl. No. 3990/06.

46) ECtHR 6 April 2004, Youatou v UK, Appl. No. 12010/03.

47) ECtHR 23 September 2003/26 July 2005, N. v Finland, Appl. No. 38885/02.

48) ECtHR 18 October 2005, Halko v Croatia, Appl. No. 30365/04.

49) E.g. Cruz Varas, supra note 37; Osmanov, supra note 37; Svarca, supra note 29. 


\subsubsection{Beneficiaries Belonging to an Ethnic Minority or Forming Part of a Minority Group that Is Discriminated Against (Articles 2 and 3 ECHR)} This group of beneficiaries of interim measures is comprised of persons belonging to an ethnic minority/a group discriminated in their country of origin, who had been ordered to leave a Member State and who claim that, if they are returned, they run a high risk of being murdered/sentenced to death, subjected to torture or not receiving a fair trial. States/territories where the beneficiaries felt a fear of returning to have been, e.g., Kosovo, ${ }^{50}$ Russia, ${ }^{51}$ Somalia, ${ }^{52}$ Sri Lanka, ${ }^{53}$ Syria ${ }^{54}$ and Turkmenistan. ${ }^{55}$

In a Swedish case, the petitioners alleged, inter alia, that because of their Albanian ethnicity they were persecuted in Kosovo by the Serbian population and that one of them had been abused sexually on one occasion by Serbian police. They requested the adoption of interim measures to stay the deportation because they believed that they would be persecuted if they returned and the Court issued a provisional measure on their behalf.56 The order of deportation to Kosovo of other applicants, who had argued that due to their Romanian origin their lives would be in danger if they were deported since they would be attacked by members of the Kosovo Liberation Army, was also stayed. ${ }^{57}$

In a Dutch case, where an interim measure was issued, the applicant had argued that if deported to north-Somalia there was a great risk that he would be subjected to ill-treatment because he belonged to the 'Reer Mar' ethnic minority. Since he did not have any clan or family ties to the 'relatively secure' areas, there was a strong possibility that he would be forced to live in camps for displaced persons, whose conditions were well-known as inhuman..$^{58}$

A number of Chechens benefited from interim measures, where the plaintiffs alleged that if they were extradited by Georgia to Russia they ran the risk of being sentenced to death and of being tortured for their activities and their Chechen ethnic origin. The applicants had been captured on the border of Georgia while attempting to enter illegally with dangerous weapons. The Russian authorities requested extradition accusing the prisoners of terrorist activities. The interim measures were lifted when Russia promised that the petitioners would be granted due process, access to medical treatment and legal aid. ${ }^{59}$

\footnotetext{
50) Haziri, supra note 29; ECtHR 10 March 2005, Berisha v Macedonia, Appl. No. 60855/00.

51) ECtHR 12 April 2005, Shamayev a.o. v Georgia/Russia, Appl. No. 36378/02.

52) ECtHR 1 November 2007, Salah Sheekh v Netherlands, Appl. No. 1948/04.

53) Venkadajalazarma, supra note 11; ECtHR 17 February 2004, Thampibillai $v$ Netherlands, Appl. No. 61350/00.

54) Salah Sheekh, supra note 52.

55) ECtHR 19 June 2008, Ryabikin v Russia, Appl. No. 8320/04; ECtHR 23 October 2008, Soldatenko $v$ Ukraine, Appl. No. 2440/07.

56) Haziri, supra note 29.

57) Berisha, supra note 50.

58) Salah Sheekh, supra note $52, \$ 6,38,135,136$.

59) Shamayev, supra note 51, \$6, 24 (Georgia violated Article 34 due to incompliance with interim measure).
} 
An imminent extradition of a man from Turkmenistan, who resided in Russia, also prompted the adoption of an interim measure. The petitioner had claimed that, if he were extradited, he would risk being tortured and mistreated due to his Russian ethnic origin and provided several reports on the situation in Turkmenistan, which referred to serious and repeated violations, especially with respect to ethnic minorities, including Russians. ${ }^{60}$ In another Turkmen case, the extradition was stayed of a person who alleged that, if returned, he risked being convicted without due process because of his ethnic origin and being dealt with in a fashion contrary to Article $3 .{ }^{61}$

Finally, there are a lot of reported cases in which provisional measures have been adopted to stay imminent expulsions of Tamils to Sri Lanka, where an internal armed conflict was taking place between the outlawed Tamil Tigers that was fighting against the government. In a case against the Netherlands, the applicant held that, because he belonged to the Tamil ethnic group in Sri Lanka and due to the collaboration that he had provided to the Tigers, if he were deported his life would be at a real risk and he would run a real risk to be exposed to ill-treatment treatment by the Sri Lankan authorities. ${ }^{62}$ More recently, in 2007 the Court has asked the UK Government to stay the removal of refused asylum seekers from Sri Lanka, pending the hearing by the Court of several communicated cases related to forced returns of Tamils by EU countries to Sri Lanka, having regard to the current security situation in that country. ${ }^{63}$ It also voiced its concerns as to the mounting numbers of similar Rule 39 applications being filed with the Court by Tamils facing removal to Sri Lanka from the UK (and other Member States). By October 2007, the Court had issued interim measures in 22 cases. The Court held that Rule 39 had been applied on each occasion a measure had been requested by an ethnic Tamil, and concluded that, pending the adoption of a lead judgment in one or more of the applications communicated, Rule 39 should continue to be applied in any cases brought by a Tamil seeking to prevent his removal. ${ }^{64}$ In its letter addressed to the British Government the Court also expressed its hope that, rather than being required to issue a provisional measure in every case, the Government would assist the Court by refraining for the time being from issuing removal directions in respect of Tamils who claim that their deportation might expose them to the risk of ill-treatment. ${ }^{65}$ In his reply, the UK Agent, inter alia, set out the conclusions of a Home Office Note on Sri Lanka and the findings of the Asylum and Immigration Tribunal in a certain case and concluded that the

\footnotetext{
60) Ryabikin, supra note 55.

61) Soldatenko, supra note 55; Press release, March 2007.

62) Venkadajalazarma, supra note 11, \$5, 56, 61, 68.

63) ECtHR, Letter Registry, 23 October 2007 (ECHR-LEO,IRCO/LCA gm) [on file with authors].

64) The same can be said viz. other countries: ECtHR S. v France, Appl. No. 43022/06.

65) ECtHR S.S. $v$ UK, Appl. No. 34274/08, lodged on 22 July 2008; ECtHR S.L. v UK, Appl. No. 42923/08, lodged on 9 September 2008 (Statement of Facts, 10 September 2009). Also: NA., supra note $13, \$ 5,20-21$.
} 
UK did not consider that the situation in Sri Lanka warranted the suspension of removals of all Tamils with claims of fear for ill-treatment. Each case had to be assessed on its merits against the available evidence. The UK was accordingly not in a position to assist Strasbourg by refraining from issuing removal directions in all such cases on a voluntary basis. Finally, the Agent stated that the UK would continue to make every effort to comply with any interim measures in accordance with their ECHR obligations and its long-standing practice. However, in the circumstances, the UK suggested that the difficulties posed by the increasing numbers of Rule 39 requests by Tamils could best be addressed through the adoption of a lead judgment by the Court and that the Government stood ready to co-operate with the Court to bring such a case to an early conclusion. ${ }^{66}$ In the period 2007-July 2008 the Court issued measures in respect of 342 Tamil applicants who claimed that their return from the UK would expose them to ill-treatment. ${ }^{67}$

\subsubsection{Beneficiaries in Danger because they Are Accused of Committing Adultery or Risk Being Subjected to Genital Mutilation (Articles 2 and 3 ECHR)}

This group is made up of women who allege that if they are forcibly returned to their country of origin they would be subjected to female genital mutilation (FGM) (Article 3) or that they run the risk of being murdered by family members for having committed adultery (Articles 2 and 3 ).

With regard to the fear of being murdered as punishment for having engaged in sexual relations out-of-wedlock, three cases, one concerning Nigeria and two concerning Iran can be mentioned. In the first case, in 1997 two consecutive requests for an interim measure to stay the expulsion of an Iranian woman, who claimed that she had been arrested by revolutionary guards and taken to prison in Shiraz, Iran, due to false information that she had committed adultery and converted to Christianity, followed by an oral proclamation of death sentence through stoning, but without receiving any written judgment, were rejected by the Acting President of the Commission and by the Commission itself. ${ }^{68}$ However, in 1998 the European Commission did indicate an interim measure - which was later confirmed by the Court - to stay the deportation of a petitioner to Iran (in the light of Article 3) because she might be stoned to death as punishment for having committed adultery. ${ }^{69}$ In a third case, interim measures were adopted in 2004 by the Court itself in the light of Articles 2, 3 (and Article 1 Protocol 13), ${ }^{70}$ where

66) NA., supra note $13, \$ 21$.

67) Ibid., $\$ 22$.

68) ECommHR 19 October 1998, Hassanpour-Omrani v Sweden, Appl. No. 36863/98.

69) ECommHR 28 November 1999, Jabari v Turkey, Appl. No. 40035/98; ECtHR 11 July 2000, Jabari $v$ Turkey, Appl. No. 40035/98, \$6, 14-15, 24-28.

70) While the beneficiary had only alleged a violation of Article 3, the situation was also analysed by the Court in the light of Article 2 ECHR and Article 1 Protocol 13. 
the petitioner alleged that, for having committed adultery and expecting her lover's child, her life would be in danger if she were returned to Nigeria, as she could be executed under the Sharia laws or killed by individuals. ${ }^{71}$

There are in total three reported cases on the issue of FGM, two concerning removal to Nigeria and one concerning removal to Tanzania. The Court issued an interim measure in 2002 suspending the deportation of a woman in view of the alleged risk of being subjected to FGM if returned to Tanzania. ${ }^{72}$ Some years later, a deportation order to Kenya of a mother and daughter was stayed because one of them could be subjected to FGM. Here it was held that even though the mutilation was prohibited by law in Kenya and the government had condemned the practice, it was a practice that was still carried out. ${ }^{73}$ In a similar case, the Court also suspended the deportation of a mother and daughter to Nigeria. In the case of the daughter it was argued that, if deported, she would be subject to FGM, and as to the mother it was alleged that she would be subject to infibulation, a more severe form of FGM. ${ }^{74}$ The FGM cases are exclusively related to African countries.

\subsection{Cases in which Only Physical Integrity Is Protected (Article 3 ECHR), Some- times Possibly in Combination with the Prohibition of Slavery or Forced Labour (Article 4 ECHR)}

In general, these are situations in which there is an order of deportation/extradition and the beneficiaries claim that their physical integrity would be at risk if returned to their country due to: (a) the (threat of) imposition of an irreducible life imprisonment sentence, (b) the danger of being subdued into slavery or (c) the physical danger as a result of their religious convictions. Interim measures have also been adopted (d) to protect nationals of non-Member States, who are about to be expelled and are allegedly in poor health. Before exemplifying situations in which interim measures have been adopted to protect rights under Article 3, it should be mentioned that most cases concerning physical integrity have already been analysed in the previous section. This is generally due to the fact that in the majority of the cases the rights to physical integrity and to life are protected simultaneously.

Cases where interim measures are adopted to stay deportation due to a fear that the applicant may be sentenced to life imprisonment in the receptor State which, according to meanwhile settled case-law, may indeed raise an issue under Article $3^{75}$ - are not very common (yet). In an early French case where Article 3

\footnotetext{
71) Bello, supra note 20.

72) ECtHR 1 July 2003, Lunguli v Sweden, Appl. No. 33692/02.

73) ECtHR 1 February 2007, Omoregbee $v$ Sweden, Appl. No. 26834/05.

74) ECtHR 8 March 2007, Collins and Akaziebie v Sweden, Appl. No. 23944/05.

75) ECtHR 12 February 2008, Kafkaris v Cyprus, Appl. No. 21906/04, \$97.
} 
was invoked, the Court issued an interim measure to suspend the extradition of an American to the US where he was wanted for murder, but where the person concerned only risked life imprisonment without any possibility of a reduction in his prison sentence. ${ }^{76}$ In another reported case an interim measure was granted with regard to pending extradition of the applicant to the US, from where he had escaped during criminal proceedings on charges, inter alia, of fraud, belonging to a criminal organisation and money laundering. He had been sentenced to 845 years of prison and he alleged that his deportation to the US would be a violation of Article 3 because he would have to serve an irreducible life sentence. ${ }^{77}$

In the area of alleged slavery there is as yet very little reported case-law. In a Swedish case, the Court adopted an interim measure to stay the deportation of a Mauritanian, claiming that he risked being enslaved as punishment for having left his country, if forcibly returned. ${ }^{78}$ Quite recently, an interim measure was issued to suspend the deportation of a woman who claimed to have been the victim of trafficking for the purposes of forced prostitution in Uganda and the UK, and complained under Articles 3 but also Article 4 that there was a real risk that if she were returned she would again fall into the hands of traffickers and be subjected to ill-treatment and forced sexual labour. ${ }^{79}$ These cases are a clear indication that Article 4 may play an important role in future cases concerning expulsion with regard to alleged victims of trafficking and/or sexual exploitation.

An interim measure has also been adopted to protect a person allegedly in danger due to his religious convictions. In fact it concerned an Iranian citizen who claimed that if the deportation order were implemented, his personal integrity would be at risk for having converted to Christianity. ${ }^{80}$

Finally, like in regular detention situations, the Court can also resort to provisional measures to oblige a Member State about to expel or extradite an applicant, to have that applicant medically examined. For example, in a case dating from 2010, the President, after having issued interim measures to stay an imminent expulsion of the applicants to Iran/Iraq, ${ }^{81}$ decided to indicate to Turkey, that an applicant should be examined by a psychiatrist in a fully equipped state hospital for diagnosis of his mental state. ${ }^{82}$ This decision was the logical and immediate result of a set of contradictory letters/information and a psychological report received by the Court. In a first letter, the main applicant, who had allegedly been held in detention for 17 months, wished to withdraw his application. This letter was followed by a notification from the applicant's representative that the appli-

\footnotetext{
76) ECtHR 14 December 2000/3 July 2001, Nivette v France, Appl. No. 44190/98.

77) Weiss, supra note 16.

78) ECtHR 19 January 1999, Ould Barar v Sweden, Appl. No. 42367/98.

79) ECtHR 1 December 2009, M. v UK, Appl. No. 16081/08.

80) ECtHR 1 June 2006, Mohammadi v Netherlands, Appl. No. 5140/06.

81) ECtHR 13 April 2010, Tehrani v Turkey, Appl. No. 32940/08, 41626/08, 43616/08, $\$ 3$.

82) Ibid., $\$ 5$.
} 
cant wished to pursue his application, and the reception some days later of two more letters - through the representative, saying that the applicant wanted to be deported to Iran where his life would be in danger. Finally, a psychological report from a psychologist was received, indicating depressive symptoms, stress and anxiety disorder and the need of urgent psychological/psychiatric support. It was also stated by the representative that the applicant wished to return to Iran which meant committing suicide and that he considered this to be better than the vagueness of his present situation. ${ }^{83}$

\subsection{Cases in which Respect for Privacy and Family Life Has Been Protected (Article 8 ECHR)}

Expelling persons from a country in which they have spent a significant part of their life and in which their close relatives live may lead to a - subsequently unjustified - interference with their right to family life (Article 8). ${ }^{84}$ Persons whose family life may be adversely affected if forcibly returned to their home country/a third country may exceptionally benefit of the suspension of their deportation through an interim measure. ${ }^{85}$

Given that the right to family life is not an absolute right, and can thus be restricted under certain circumstances, a review of the jurisprudence shows that, above all, the organs of the European system, in examining a request for interim measures, have had to resolve the conflict between the right to have family life respected on the one hand and the right of a State to prevent crimes and to regulate its migratory policy on the other hand. The cases in which an interim measure is requested, therefore concern situations in which aliens, after having been tried for the commission of a crime, have been ordered to abandon the country or who are illegal aliens under an order of deportation. ${ }^{86}$

While examining the merits of a case, the Court must often weigh whether an order of deportation is proportionate to the State's obligation to respect family life, and while there are quite a few cases in which the Court in its judgment on the merits found a violation of Article $8,{ }^{87}$ in contrast, during the preliminary

\footnotetext{
83) Ibid., $\$ 20$.

84) The ECHR does not guarantee migrants the right to enter/reside in a Member State, nor does it impose a general obligation on States to respect in which State a couple wishes to fix its residence or to accept the presence on their territory of non-national spouses, provided there is no obstacle to develop their family life in their countries of origin.

85) It should be emphasized that some cases in which interim measures have been requested, concern, besides a claim under Article 8, also a claim under Article 3, so that, even if a measure has been awarded, it remains unclear whether it has been granted to protect Article 3, 8 or both. Therefore, our examples are restricted mainly to pure Article 8 - applications.

86) ECtHR 13 February 2001, Ezzouhdi v France, Appl. No. 47160/99, \$5-6.

87) Indeed, it is often not so much a question of whether Article 8 is/is not restricted because it doubtlessly is, but the analysis turns on whether a balance is struck between the interest of persons that their family life is respected on the one hand and society's interest in that crimes be prevented, public order
} 
stages of the proceedings a request for an interim measure to suspend a deportation order in a case in which Article 8 is invoked, will only extremely seldom meet the requirement that the damage must be irreparable, and such requests will thus usually be rejected by the Court.

For example, on 30 March 1999 the Court rejected a request for an interim measure to stay the deportation of the Moroccan applicant who had been sentenced to a prison sentence for having dealt drugs on several occasions, to his country of origin. ${ }^{88}$ In another case an interim measure was denied to stay the deportation of an applicant from Norway to Nigeria, who had had a relationship with one of the other applicants since the spring of 2001 and had been married since 2 February 2003, a union from which on 20 September 2006 a child had been born. The applicants had claimed that in the event of the first applicant (father) being expelled to Nigeria it would not be possible for the second and third applicants (mother and child) to follow him to settle there, and that the expulsion of the father would thus lead to the family being split, which would have particularly adverse consequences for the wife and the child and would amount to a disproportionate interference with the applicants' right to respect for private and family life. According to the Court, the circumstances underlying the application were not of the kind to which, in the Court's practice, Rule 39 was applied. ${ }^{89}$

The refusal of the Court to issue interim measures in Article 8 expulsion cases stems from the idea that the damage that could result from the deportation of an applicant is not irreparable because it can simply be remedied by subsequently giving the applicant the permission to re-enter the country. Therefore, it seems important, when asking for an interim measure in an Article 8 case, to demonstrate very prima facie that, apart from the facts that (a) there exists true family life (meaning not so much that the petitioners have a wife or children but that they have an effective family life, and this implies that, although, in principle, cohabitation is important other elements may be used to show that in practice there exist consolidated family ties), that (b) if removed, no meaningful family life whatsoever will be possible in the receiving country and the applicant will with certainty be refused re-entry into the expelling country where he can consume his family life. But even in such a case, success as to the requested measure does not seem guaranteed.

However, in some very exceptional cases the Strasbourg organs have adopted an interim measure. E.g. the impending deportation of the parents within an

\footnotetext{
guaranteed and immigration controlled on the other hand, and the decision of which element should prevail depends on various factors, namely (a) is there true family life, (b) the moment in which the family was formed, (c) the existence of family ties to the place of origin, (d) possibilities of family members to live in the third State.

${ }^{88)}$ E.g. Ezzouhdi, supra note $86, \$ 5-6$.

89) ECtHR 31 July 2008, Omoregie v Norway, Appl. No. 265/07, \$37.
} 
Indian family, comprising three generations and living together in the UK, to India, while the grandparents and the children were being allowed to settle in the UK, which was alleged to constitute a violation of Article 8 (family life), led the Commission in the 1970 s to adopt an interim measure staying the removal. ${ }^{90} \mathrm{In}$ a more recent case, measures were adopted on 25 November 2005 by the Court to stay a deportation order to Macedonia. The petitioner had alleged that the deportation measure was disproportionate and therefore violated Article 8, since it would be allegedly practically impossible for him to enjoy any kind of meaningful form of family life with his two young children if he had to do so from Macedonia. ${ }^{11}$ In a German case, interim measures were adopted to stay a deportation order of a woman whose special residency for family reunification was not extended and who maintained that the German decision not to renew her permit and the deportation order to Turkey violated her right to family life (Article 8). ${ }^{92}$

Separating young children from one parent living in a Member State to deport them to another country where the other parent lives, for example following a judgment with regard to parental authority or custody, may also cause serious and irreparable damage to the persons concerned and may convince the Court to indicate an interim measure.

Indeed, interim measures have been adopted to stay the order to return a minor, who had been taken by her mother to Turkey (where she decided to live) without the authorisation of the father (who lived in Israel), and whom the Turkish authorities had decided to return to Israel. In this case the Court had to consider the rights of the parents, the interest of the minor and the public policy of the State. ${ }^{93}$ In a similar case, the return ordered by a Swiss court of a minor living with his mother in Lausanne, to Israel, where his father lives, which according to the applicants violated their right to family life, led the Court on 27 September 2007 to indicate the interim measure concerned to Switzerland. ${ }^{94}$

On 18 February 2010, rather uniquely, an interim measure was granted in relation to an Article 8 and 6 complaint, to stay the imminent removal to Jamaica of an applicant with a poor immigration history and criminal convictions, suffering from significant mental health difficulties and who had not physically met one of his children who was born whilst he was serving his sentence. The applicant was, however, involved in care proceedings and was seeking contact rights with his child. In fact the applicant sought to persuade the Court that irreparable harm would be caused to himself and to his children if he was removed (a) prior to the Family Court being in a position to assess his suitability to have contact or to be considered as an alternative carer, (b) given that his significant mental health

\footnotetext{
90) ECommHR 9 July 1980, Uppal v UK, Appl. No. 8244/78 (admissible under Article 8).

91) ECtHR 11 April 2006, Useinov v Netherlands, Appl. No. 61292/00.

92) Taskin, supra note 28.

93) ECtHR 6 December 2005, Ezkinazi and Chelouche v Turkey, Appl. No. 14600/05.

94) ECtHR 8 January 2009, Neulinger and Shuruk v Switzerland, Appl. No. 41615/07.
} 
difficulties would be likely to impede his ability to look after his interests in respect of regaining contact rights from abroad, and (c) given the likely outcome that he and his child (who was subject to an interim care order) would lose the opportunity of gaining any meaningful contact with one another, which was not necessarily in the child's best interest. ${ }^{95}$

\section{4. 'Dublin Transfers' and Interim Measures}

The Dublin-II Regulation, ${ }^{96}$ allocating responsibility for examining an asylum application to the EU-State where the asylum-seeker coming from a third country first crossed the border, implies that if such person is apprehended in another EU-State he will be returned to the country of first entry, mostly to countries such as Italy, Malta and Greece, being the main entrance gates to Europe. These intra-EU-transfers have prompted criticism, inter alia, from the Commissioner for Human Rights (CHR), ${ }^{97}$ the UN High Commissioner for Refugees $(\mathrm{UNHCR})^{98}$ and NGOs. ${ }^{99}$ Causes of concern include e.g., the fear that those being transferred are not always able to access an asylum procedure and are risking being returned to countries where they may be persecuted. In April 2010, in a third party intervention in Strasbourg, the CHR has held with regard to the situation in Greece, that, as regards access to the Court, although this is guaranteed in principle for every individual within Greece's jurisdiction, lodging applications and Rule 39 requests in Strasbourg appear to be very difficult in practice. Such requests introduced from/against Greece could be linked to difficulties in accessing interpretation services and lawyers, especially for people in detention, and to the lack of availability of proper legal information. ${ }^{100}$

Since 2008 quite a lot of interim measures have been issued suspending removal decisions from Austria, Belgium, Finland, France, the Netherlands, Hungary, Sweden, UK, etc., to the above-mentioned countries, in the light of allegations that such transfers may imply a risk of violation of Articles 2 and $3 .{ }^{101}$ It concerns,

95) ECtHR, Irving $v$ UK, Appl. No. 8655/10.

96) Council Regulation (EC) No. 343/2003, 18 February 2003, OJ L050, 25 February 2003.

97) Report CHR, following visit to Greece, 8-10 December 2008, CommDH(2009)6, Strasbourg, 4 February 2009.

98) UNHCR, Observations on Greece as a country of asylum, Geneva, December 2009.

99) Ivar Dale a.o., Out the Back Door: The Dublin II Regulation and illegal deportations from Greece, Norwegian Helsinki Committee a.o., Oslo/Athens 2009; Human Rights Watch, Unsafe and Unwelcoming Shores, New York, 12 October 2009.

100) The number of such requests introduced from/against Greece seems to be quite low compared to other Members. CHR, "Third party intervention", Strasbourg, 10 March 2010, CommDH(2010)9, $\$ 28$. E.g., it is said that in 2008 only 11 requests were introduced ( 5 out of scope/ 6 refused); in 2009 only 12 requests were made (5 out of scope/ 1 granted $/ 6$ refused).

101) European Council on Refugees and Exiles (ECRE), "ECtHR Interim Measures to stop Dublin transfers"; President ECtHR, Letter with provisional measure, 10 June 2010, X. v Netherlands, Appl. No. 30383/10 [on file with authors]. 
e.g. transfers to Greece of Iraqi/Somali asylum-seekers, an Afghan NATOinterpreter, ${ }^{102}$ an unaccompanied 16-year old Afghan having contracted hepatitis-B while detained in an allegedly overcrowded Greek detention centre, where he had allegedly been beaten by the police. ${ }^{103}$ On one occasion, in 2008, the UK was requested not to expel an Iranian to Greece in light of an 2008 UNHCR report, stating that given EU-States' obligation to ensure access to fair and effective asylum procedures, including in Dublin-II cases, Governments are advised to refrain from returning asylum seekers to Greece under the Regulation until further notice. The interim measure would remain in force pending UK confirmation that the applicant, if removed to Greece, will have opportunity in Greece to apply for an interim measure in case of his onward expulsion to Iran. The UK was invited to avail itself of any bilateral arrangements with a view to seeking such confirmation. ${ }^{104}$ In June 2010 another measure was indicated to the Netherlands, staying an expulsion to Greece for the duration of the Strasbourg proceedings. in view of the applicants' assertion that they might be returned (directly/indirectly) to Somalia without a rigorous scrutiny by Greece of their Article 3 - claim, without the applicants having a proper opportunity to request the Court to intervene, the security situation in South and Central-Somalia, the fact that there are a number of Somalian Dublin-II transfer cases to Greece pending in Strasbourg. ${ }^{105}$ As to Italy and Malta, cases in which measures have been indicated to stay Dublin transfers concern, e.g. a woman under age, a woman with a 5-month-old child, adult men, and - in the Italian cases - where evidence was presented in which the authorities' age determination was questioned, and where injuries/trauma sustained during a prior period of homelessness (in Italy) were outlined. ${ }^{106}$

\section{Conclusions}

One of the major virtues of today's Strasbourg monitoring system is the possibility to ask for a legally binding interim measure in urgent cases, in order to prevent irreparable harm being done to the applicant's rights that cannot be remedied by a subsequent judgment on the merits. In literally hundreds of cases per year, measures are adopted with a rapidity consonant with the situation that the Court is

\footnotetext{
102) Ibid.

103) Hungarian Helsinki Committee, "The European Court of Human Rights suspends return of seriously ill Afghan minor asylum seeker from Hungary to Greece under the Dublin Regulation”, Budapest, 3 March 2010.

104) ECtHR 2 December 2008, K.R.S. $v$ UK, Appl. No. 32733/08 (manifestly ill-founded: no proof for risk of onward removal to third country without real opportunity of applying for interim measure; assurances obtained from Greek Dublin-Unit: see letter that asylum applicants have right to appeal against expulsion decision and to seek interim measures).

105) $X$., supra note 101.

106) ECRE, supra note 101.
} 
made aware of. The acceptance rate of interim measures has grown in the past years from less than one in five to one in four, which is high if compared to the extremely low success rate of applications tout court, and it may be assumed that this is the result of the mounting quality of the requests, which, in turn, is due to the growing interest/involvement of (more specialised) lawyers and NGOs.

Most beneficiaries are foreigners, who, having been denied political asylum or residency, wish to avoid deportation because in the receptor State they allegedly run some type of risk related to one of the ECHR rights, i.e. political violence, persecution, capital punishment, irreducible life sentences, FGM, situations which are generally related to the right to life (Article 2, Protocol 6/13) and the prohibition of torture (Article 3). The risk may come from the State but also from private actors. The cases studied show that the beneficiaries have always been the alleged victims and sometimes other close family members, but also, exceptionally, groups of persons (mostly members of (ethnic) groups). Rather few beneficiaries receive protection due to their refusal to leave thereby being separated from their families (Article 8) or because in their country of origin they would not find the necessary drugs/medical treatment for their disease/medical situation (Article 3) or receive an unfair trial (Article 6). The large majority are under orders to leave because they are illegally in a Member State, others are about to be deported as a consequence of a punishment imposed on them for crimes committed in the Member State/their country of origin. The occurrence of new factual situations submitted for consideration, such as the fear of being trafficked or used as sex workers, if deported, seems to have resulted in a slight expansion of the scope of interim measures to other rights, such as the prohibition of slavery/ forced labour (Article 4), while the number of cases related to the respect for family life, which for a long time, largely stayed below the horizon, is gradually growing.

Most often interim measures are adopted to stay forced removals to third States. There seems to be a clear tendency with the Court to halt removals to countries which it implicitly perceives as suspect countries, such as Uzbekistan, Belarus, Somalia, Iraq, Jordan or Tunisia. Indeed, there seems to be some assumption that a deportation to such countries is suspect, and even diplomatic guarantees, which sometimes lead the Court to reject interim measures to stay deportations to non-suspect third countries, are deemed temporarily insufficient/ unsatisfactory for the Court to give its approval to the expulsion/extradition. In contrast, only very exceptionally removals have been stayed towards an ECHR Member State. This is because the Court supposes that Members will fully comply with their ECHR obligations, and that applicants will therefore be able to submit interim measures in the receiving State. In the past there have been occasional cases, both regarding older and newer Member States after their return to democracy and/or who are struggling with internal armed actors (Spain, Turkey, 
Russia), where interim measures have stayed expulsions/extraditions. Nowadays, however, the fear for indirect expulsion from certain ECHR Member States to unsafe third states, as well as alleged substandard accommodation and access to asylum procedures in certain States after so-called Dublin-transfers from most Member States in application of an EU-regulation, seem to lead to more requests for/grants of interim measures towards Member States. 